Bioeduca: Journal of Biology Education
$\frac{\text { http://iournal.walisongo.ac.id/index.php/bioeduca }}{\text { ISSN 2714-8009 (print), 2715-7490 (online) }}$
Volume 3, Nomor 2, Tahun 2021
Hal. 146 - 159

\title{
Analisis Potensi Penerapan STEAM (Science, Technology, Engineering, Art, Mathematics) pada Kurikulum 2013 Bidang Studi Biologi SMA Kelas X
}

\author{
Amalia Prabandani Halim ${ }^{1 *}$, Fenny Roshayanti ${ }^{2}$ \\ ${ }^{1,2}$ Prodi Pendidikan Biologi, Universitas PGRI Semarang \\ Email : amaliaprabandani11@gmail.com
}

\begin{tabular}{|c|c|}
\hline Informasi Artikel & ABSTRAK \\
\hline $\begin{array}{l}\text { Submit: } 08-10-2020 \\
\text { Diterima: } 15-09-2021 \\
\text { Dipublikasikan: } 30-09-2021\end{array}$ & $\begin{array}{l}\text { STEAM (Science, Technology, Engineering, Art, Mathematics) } \\
\text { adalah pendekatan pembelajaran yang menggabungkan } 5 \text { aspek } \\
\text { yaitu sains, teknologi, teknik, seni, dan matematika yang dapat } \\
\text { diterapkan dalam berbagai disiplin ilmu. Pendekatan STEAM } \\
\text { sangat popular dimasa sekarang, sehingga dengan adanya } \\
\text { penelitian ini diharapkan proses pembelajaran dapat dilaksakan } \\
\text { menggunakan pendekatan STEAM. Penelitian ini bertujuan } \\
\text { untuk mengetahui potensi penerapan STEAM pada Kurikulum } \\
2013 \text { Bidang Studi Biologi SMA Kelas X. Penelitian ini } \\
\text { merupakan penelitian deskriptif kualitatif dengan subjek } \\
\text { penelitian perangkat Kurikulum } 2013 \text { yaitu Kompetensi Dasar } \\
\text { Bidang Studi Bioligi SMA Kelas X dan buku teks yang digunakan } \\
\text { dalam proses pembelajaran. Hasil penelitian menunjukkan } \\
\text { bahwa Kurikulum } 2013 \text { cukup berpotensi untuk diterapkan } \\
\text { STEAM. Fakta tersebut dapat dikembangkan dan diintegrasikan } \\
\text { dengan pendekatan STEAM sehingga mampu meningkatkan } \\
\text { dan mengembangkan kemampuan yang dimiliki oleh setiap } \\
\text { peserta didik. } \\
\text { Kata kunci: STEAM; kurikulum } 2013 \text {; biologi }\end{array}$ \\
\hline Penerbit & ABSTRACT \\
\hline $\begin{array}{l}\text { Program Studi Pendidikan } \\
\text { Biologi, Fakultas Sains dan } \\
\text { Teknologi, UIN Walisongo } \\
\text { Semarang }\end{array}$ & $\begin{array}{l}\text { STEAM (Science, Technology, Engineering, Art, Mathematics) is } \\
\text { a learning approach that combines } 5 \text { aspects, namely science, } \\
\text { technology, engineering, art, and mathematics that can be } \\
\text { applied in various disciplines. The STEAM approach is very } \\
\text { popular nowadays, so with this research it is hoped that the } \\
\text { learning process can be carried out using the STEAM approach. } \\
\text { This study aims to determine the potential application of STEAM } \\
\text { in the } 2013 \text { Curriculum for Biology at SMA Class X. This } \\
\text { research is a qualitative descriptive study with the research } \\
\text { subject being the } 2013 \text { Curriculum, namely Basic Competencies } \\
\text { for Biology at SMA Class X and textbooks used in the learning } \\
\text { process. The results show that the } 2013 \text { Curriculum has the } \\
\text { potential to be applied to STEAM. These facts can be developed } \\
\text { and integrated with the STEAM approach so as to improve and } \\
\text { develop the abilities possessed by each student. } \\
\text { Kev words: STEAM: curriculum 2013: biologv }\end{array}$ \\
\hline
\end{tabular}

Copyright C2021, Bioeduca: Journal of Biology Education

Amalia Prabandani Halim et al. - Analisis Potensi Penerapan STEAM (Science, 


\section{PENDAHULUAN}

Saat ini dunia telah memasuki abad ke 21 yang ditandai sebagai abad keterbukaan atau abad globalisasi yang artinya kehidupan manusia pada abad ke 21 mengalami perubahan dari tata kehidupan sebelumnya. Abad ke 21 menuntut sumber daya manusia yang kerkualitas dengan memiliki keterampilan teknologi dan manajemen informasi, belajar dan berinovasi, membangun kemandirian sebagai modal dasar dalam menghadapi era globalisasi (Apriliana et al.,2018; Wijaya et al., 2016). Adanya tuntutan tersebut meminta berbagai terobosan dalam berpikir, menyusun konsep dan tindakan-tindakan yang tepat. Salah satu cara yang dalam menciptakan sumber daya manusia yang berkualitas adalah dengan memperbaiki mutu pendidikan. Pendidikan di masa sekarang dihadapkan pada tantangan untuk menyiapkan dan membekali peserta didik supaya memiliki keterampilan abad 21 . Menurut Siswanto (2018), keterampilan abad 21 meliputi keterampilan berpikir kritis, pemecahan masalah, komunikasi, kolaborasi dan kreativitas. Keterampilan tersebut harus dimiliki peserta didik untuk dapat menghadapi tantangan abad 21 sehingga kualitas pendidikan juga dapat meningkat. Untuk menghadapi tantangan abad 21, pemerintah Indonesia melakukan perubahan dan penyempurnaan kurikulum yaitu dari KTSP 2006 menjadi Kurikulum 2013.

Kurikulum 2013 merupakan kurikulum yang mengutamakan pemahaman, keterampilan, dan pendidikan karekter (Handayani, 2018). Menurut Permendikbud No. 69 Tahun 2013, tujuan dibentuknya kurikulum 2013 adalah mempersiapkan manusia Indonesia agar memiliki kemampuan hidup sebagai pribadi dan warga negara yang beriman, produktif, kreatif, inovatif, afektif serta mampu berkontribusi pada kehidupan bermasyarakat, berbangsa, bernegara, dan berperadaban dunia.hal ini dimaksudkan agar pengetahuan dan keterampilan peserta didik di Indonesia dapat tersusun secara utuh dalam mempelajari suatu materi dari berbagai sisi disiplin ilmu (Lestari, 2018). Menurut Katawi et al. (2017), dalam pelaksanaannya, kurikulum 2013 belum berjalan dengan baik terlebih semua mata pelajaran memerluakan penyetaraan antara soft skill dan hard skill, termasuk mata pelajaran biologi.

Biologi merupakan ilmu yang memepelajari makhluk hidup dan kehidupannya. Materi biologi tidak hanya mengkaji materi-materi konkret yang ada di alam, melainkan juga mengkaji materi-materi abstrak yang ada di dalamnya seperti prosesproses kimiawi yang terjadi di dalam tubuh, sistem hormonal, dan sistem koordinasi (Sudarisman, 2015). Dengan demikian biologi memerlukan kemampuan berpikir tingkat tinggi seperti berpikir secara kritis, logis, dan analitis sehingga dalam pelaksanaannya diperlukan berbagai alat dukung seperti penggunaan media pembelajaran dan sarana laboratorium.

Sains modern, khususnya biologi bertujuan melibatkan siswa dalam memahami bagaimana keterlibatan proses ilmiah dan mendorong mereka untuk berpikir tentang tantangan sosio-saintifik yang dihadapi masyarakat (Suwono et al., 2017). Pendidikan sains modern harus menawarkan konteks yang kaya untuk 
mengembangkan berbagai keterampilan abad 21, seperti keterampilan berpikir kritis, keterampilan dalam proses pemecahan masalah, literasi informasi, dan berbagai praktik sains lainnya. Pembelajaran abad 21 adalah membangun kemampuan belajar masing-masing peserta didik dan mendukung perkembangan menjadi pebelajar sepanjang hayat, aktif dan mandiri (Pratiwi et. al., 2019). Oleh karena itu, guru perlu mendorong siswa untuk berinteraksi dengan pengetahuan untuk memperkuat keingintahuan siswa, keterampilan mengidentifikasi masalah dan membentuk kemampuan baru dengan orang lain melalui desain pembelajaran yang menarik salah satunya dengan menerapkan pembelajaran STEAM dalam kegiatan belajar mengajar.

Pembelajaran STEAM (Science, Technology, Engineering, Art, Mathematics) adalah pendekatan pembelajaran yang menggabungkan 5 aspek dan dapat diterapkan dalam berbagai disiplin ilmu yang mampu meningkatkan kompetensi siswa dalam menghadapi tantangan abad 21 melalui keterlibatan siswa dalam proses pembelajaran (Hadinuraningsih, et al., 2017:17). STEAM (Science, Technology, Engineering, Art, Mathematics) merupakan pengembangan dari STEM (Science, Technology, Engineering, Mathematics). Istilah STEM dikenalkan oleh National Science Foundation (NSF) di Amerika Serikat pada tahun 1990-an (Sanders, 2008). STEM bukan hanya pengelompokan bidang kajian tetapi merupakan perbaduan dan pendekatan holistik untuk memecahkan masalah (DeCoito, 2014). Seiring berjalannya waktu, STEM berkembang menjadi STEAM yang diinisiasi oleh Rhode Island School of Desain yang menambahkan Art kedalam STEM. Seni (arts) dalam STEAM dapat memberikan kesempatan kepada peserta didik untuk dapat berkreasi dan berinovasi dalam pembelajaran serta menunjukkan sisi non-analitis dan sisi kreatif dari otak seseorang yang memungkinkan seseorang untuk memecahkan masalah secara kreatif (Rabkin \& Hedberg, 2011; Rachim, 2019:41; Zubaidah, 2019). Dalam penerapannya, pendekatan STEAM memberikan kebebasan kepada siswa untuk mengeksplorasi dan mendapatkan pemahaman lebih tentang berbagai disiplin ilmu yang dipelajari sebagai proses transfer pengetahuan. Beberapa negara yang sudah menerapkan pembelajaran STEAM dalam rangka menghadapi tantangan abad 21 adalah Amerika Serikat dan Korea (Daugherty, 2013; Park, 2016). Selain diintegrasikan dalam pembelajaran, mereka juga menerapkan STEAM pada kegiatan ekstrakurikuler untuk menguatkan keterampilan siswa (Fianto, 2018:8).

Berikut ini beberapa penelitian terdahulu yang mendukung peneliti untuk menggunakan STEAM (Science, Technology, Engineering, Art, Mathematics) dalam penelitian. Pertama, karya tulis yang disusun Retnowati (2020) menyatakan bahwa pembelajaran biologi dengan materi perubahan lingkungan yang terintegrasi dengan kewirausahaan berbasis STEAM dapat meningkatkan kemampuan berpikir kritis dan minat wirausaha peserta didik. Perbedaan penelitian ini dengan penelitian Retnowati terletak pada materi yang dikaji. Penelitian Retnowati dikaitkan dengan minat kewirausahaan, sedangkan penelitian ini hanya fokus pada potensi STEAM pada 
kurikulum 2013 dalam studi biologi. Kedua, karya tulis yang disusun oleh Patresia et. al. (2020) menyatakan bahwa LKS berbasis STEAM mampu memberdayakan keilmuan siswa dalam keterampilan proses. Perbedaan dengan penelitian ini terletak pada tujuan yang diharapkan. Penelitian Patresia et. al bertujuan agar LKS berbasis STEAM mampu memberdayakan keilmuan siswa dalam keterampilan proses, sedangkan penelitian ini bertujuan untuk mengetahui potensi penerapan STEAM (Science, Technology, Engineering, Art, Mathematics) pada kurikulum 2013.

Pemetaan potensi STEAM pada kurikulum 2013 penting untuk dilakukan karena pembelajaran ini merupakan salah satu pembelajaran kooperatif yang merupakan bagian dari pembelajaran konstruktivisme. Hal ini sesuai dengan pembelajaran kurikulum 2013 di mana siswa secara aktif akan membangun pengetahuan dan pemahamannya sendiri melalui proyek. Proyek yang diberikan pada pembelajaran dengan pendekatan STEAM menuntut siswa untuk dapat memahami biologi sebagai science, memanfaatkan teknologi yang sedang berkembang seperti komputasi untuk membantu menemukan konsep secara inkuiri, kemudian disajikan dengan memperhatikan etika dan estetika sebagai seni dan menampilkan bentuk-bentuk materi biologi (Coates, 2020).

Sejauh ini belum ada penelitian yang membahas mengenai potensi STEAM pada Kurikulum 2013 yang difokuskan pada studi biologi. Alasannya karena biologiidentik dengan pembelajaran hafalan, sehingga sulit jika dikaitkan dengan STEAM. Hal tersebut yang melatarbelakangi dalam pengambilan topic tentang otensi penerapan STEAM (Science, Technology, Engineering, Art, Mathematics) pada kurikulum 2013 bidang studi biologi SMA kelas X.

Tujuan penelitian ini adalah untuk mengetahui potensi penerapan STEAM (Science, Technology, Engineering, Art, Mathematics) pada kurikulum 2013 bidang studi biologi SMA kelas $X$. Melalui kajian ini dapat diperoleh informasi mengenai potensi STEAM yang dapat diterapkan dalam pembelajaran biologi SMA kelas $\mathrm{X}$.

\section{METODE PENELITIAN}

Penelitian ini dilaksanakan dengan menggunakan penelitian deskriptif kualitatif. Metode kualitatif merupakan prosedur penelitian yang menghasilkan data deskriptif berupa kata-kata dari dokumen atau catatan lapangan yang diteliti. Subjek dalam penelitian ini adalah perangkat Kurikulum 2013 yaitu Kompetensi Dasar Bidang Studi Biologi SMA Kelas $X$ dan buku teksyang digunakan siswa dalam proses pembelajaran. Data yang diperoleh berasal dari data sekunder, yaitu Kompetensi Dasar Kurikulum 2013 Bidang Studi Biologi SMA Kelas X pada KD 3.4 4.4 Materi ciriciri virus, struktur, dan reproduksinya dan KD 3.114.11 yaitu materi penanganan limbah, kemudian peneliti melakukan analisis terhadap Kompetensi Dasar yang nantinya dapat diketahui bagaimana potensi STEAM (Science, Technology, Engineering, Art, Mathematics) yang terdapat pada Kompetensi Dasar Kurikulum 2013 Bidang Studi Biologi SMA Kelas X. 
Instrumen yang digunakan dalam penelitian ini adalah kuesioner validasi produk. Dalam hal ini kuesioner digunakan sebagai acuan dalam koreksi atau merevisi produk agar produk yang dibuat menjadi lebih baik. Instrumen yang dapat membantu dalam proses analisis yang berisi indikator STEAM (Science, Technology, Engineering, Art, Mathematics). Validasi dilakukan untuk menguji kelayakan yang dibuat oleh peneliti. Berikut adalah framework dalam penelitian ini yang kemudian dikembangkan menjadi instrument penelitian.

Tabel 1. Framework Penelitian

\begin{tabular}{|c|c|}
\hline Indikator & Deskripsi Indikator \\
\hline Interdisipliner & $\begin{array}{l}\text { Interdisipliner adalah pendekatan dalam pemecahan suatu } \\
\text { masalah dengan menggunakan tinjauan berbagai sudut } \\
\text { pandang ilmu serumpun yang relevan atau tepat guna } \\
\text { secara terpadu (Thuneberg, et. al, 2017) }\end{array}$ \\
\hline Eksplorasi & $\begin{array}{l}\text { Eksplorasi dalam pendidikan adalah kegiatan untuk } \\
\text { memperoleh pengalaman-pengalaman baru melalui situasi } \\
\text { yang baru (Plucker et. al., 2018) }\end{array}$ \\
\hline Interaktif & $\begin{array}{l}\text { Model pembelajaran interaktif adalah suatu cara atau } \\
\text { teknik pembelajaran yang digunakan guru pada saat } \\
\text { menyajikan bahan pembelajaran di mana guru berperan } \\
\text { sebagai pemeran utama dalam menciptakan situasi } \\
\text { interaktif yang edukatif, yakni interaksi antara guru dengan } \\
\text { siswa, siswa dengan siswa dan siswa dengan sumber } \\
\text { pembelajaran (Shalikhah, 2016) }\end{array}$ \\
\hline Inovasi & $\begin{array}{l}\text { Inovasi pembelajaran yaitu proses belajar pada siswa yang } \\
\text { dirancang, dikembangkan dan dikelola secara kreatif dan } \\
\text { dinamis dengan menerapkan pendekatan multi kearah yang } \\
\text { lebih baik untuk menciptakan suasana dan proses belajar } \\
\text { yang kondusif bagi siswa (Chandrasegaran, 2016). }\end{array}$ \\
\hline $\begin{array}{l}\text { Fleksibilitas dan } \\
\text { Adaptabilitas }\end{array}$ & $\begin{array}{l}\text { Fleksibilitas adalah kemampuan untuk beradaptasi dan } \\
\text { bekerja dengan efektif dalam situasi yang berbeda dan } \\
\text { dengan berbagai individu atau kelompok. Fleksibilitas } \\
\text { membutuhkan kemampuan memahami dan menghargai } \\
\text { pandangan yang berbeda dan bertentangan mengenai } \\
\text { suatu isu (Huda, 2011) }\end{array}$ \\
\hline Integrasi Konten & $\begin{array}{l}\text { Science menjelaskan tentang pengetahuan dalam } \\
\text { pembelajaran yaitu mengenai konsep materi } \\
\text { Technology menjelaskan mengenai penggunaan teknologi } \\
\text { terbaru yang memudahkan siswa dalam pelaksanaan } \\
\text { aktivitas pembelajaran } \\
\text { Engineering menjelaskan tentang teknik-teknik yang } \\
\text { digunakan siswa selama penyelasaian proyek } \\
\text { Art akan memunculkan kreatifitas siswa dalam mendesain } \\
\text { proyek } \\
\text { Mathematics merupakan rumus-rumus, perhitungan } \\
\text { ataupun bangun ruang yang digunakan siswa selama } \\
\text { aktivitas pembelajaran } \\
\text { (Prameswari \& Lestariningrum, 2020) }\end{array}$ \\
\hline
\end{tabular}


Prosedur kerja pada penelitian ini adalah dengan mencermati setiap kompetensi dasar yang di dalamnya terdapat beberapa materi, selanjutnya materi tersebut dianalisis dengan berpedoman pada instrumen potensi STEAM (Science, Technology, Engineering, Art, Mathematics) yang meliputi interdisipliner, eksplorasi, interaktif, inovasi, fleksibilitas dan adaptabilitas, serta integrasi konten. Validasi dilakukan oleh pakar ahli STEAM (Science, Technology, Engineering, Art, Mathematics) dan satu guru biologi SMA kelas X. Penentuan skor didapat dari 5 skala dengan rentang 1-5. Kemudian kegiatan pembelajaran yang berpotensi STEAM ditunjukkan dengan tanda ceklis $(\checkmark)$. Materi yang sudah dianalisis dihitung jumlah skor dalam kompetensi dasar tersebut, selanjutnya menghitung persentase potensi STEAM di dalamnya menggunakan rumus berikut:

\section{Jumlah Skor KD \\ Jumlah Keseluruhan Skor \\ $\mathrm{X} 100$}

Hasil perhitungan dalam bentuk persentase disesuaikan dengan standar yang digunakan untuk menentukan kesesuaian. Standar kesesuaian tersebut diadaptasi dari penggolongan persentase dengan skala lima (Sugiyono, 2014).

Tabel 2. Rentang Persentase Potensi STEAM pada Kurikulum 2013

\begin{tabular}{|c|c|}
\hline Interval Presentase & Keterangan \\
\hline $85 \%-100 \%$ & Sangat berpotensi \\
\hline $75 \%-84 \%$ & Berpotensi \\
\hline $60 \%-74 \%$ & Cukup berpotensi \\
\hline $40 \%-59 \%$ & Kurang berpotensi \\
\hline $0 \%-39 \%$ & Sangat kurang berpotensi \\
\hline
\end{tabular}

\section{HASIL PENELITIAN DAN PEMBAHASAN}

Berdasarkan analisis yang telah dilakukan terhadap komponen 2013 yang terdiri dari Kompetensi Dasar Bidang Studi Biologi SMA Kelas X dan buku paket yang digunakan dalam pembelajaran menunjukkan bahwa pada setiap Kompetensi Dasar mencakup indikator yang diperlukan untuk dapat diterapkan pembelajaran STEAM. Adapun kegiatan pembelajaran yang berpotensi STEAM ditunjukkan pada tabel berikut.

Tabel 3. Potensi STEAM pada Kurikulum 2013 Bidang Sudi Biologi SMA Kelas X

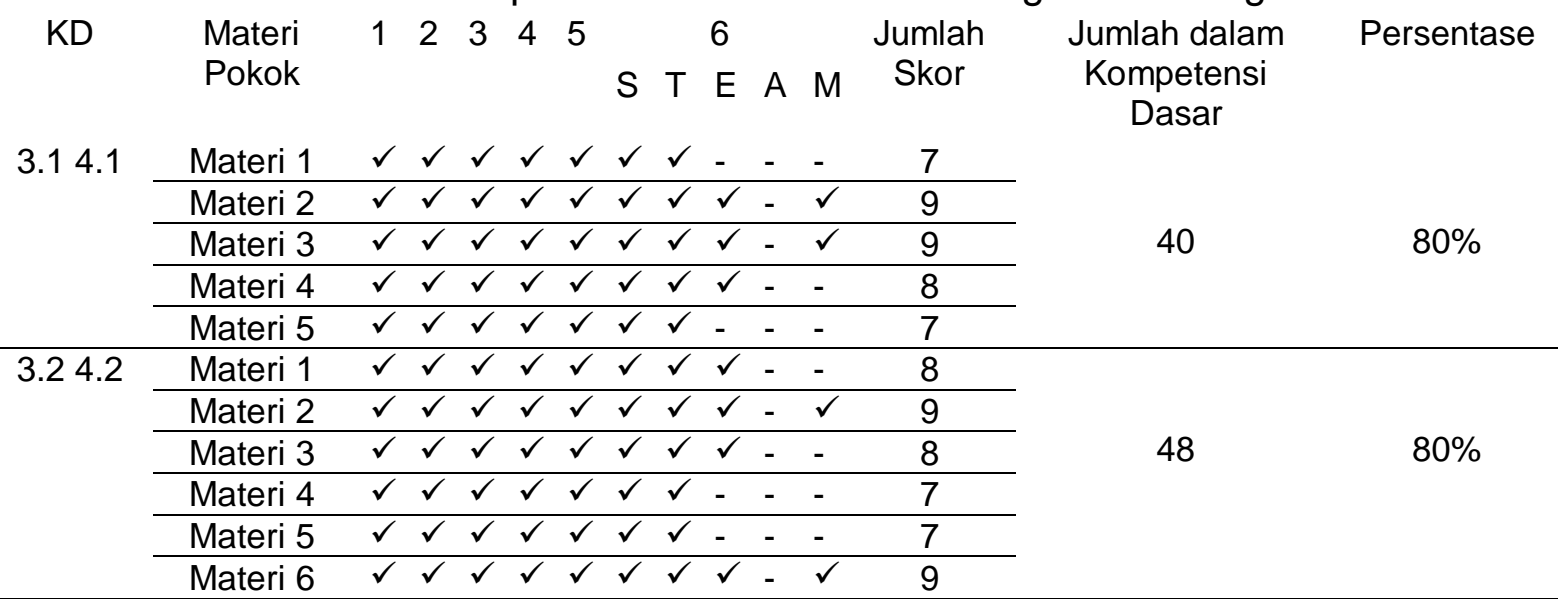

Amalia Prabandani Halim et al. - Analisis Potensi Penerapan STEAM (Science,

Technology, Engineering, Art, Mathematics) pada Kurikulum 2013 Bidang Studi 


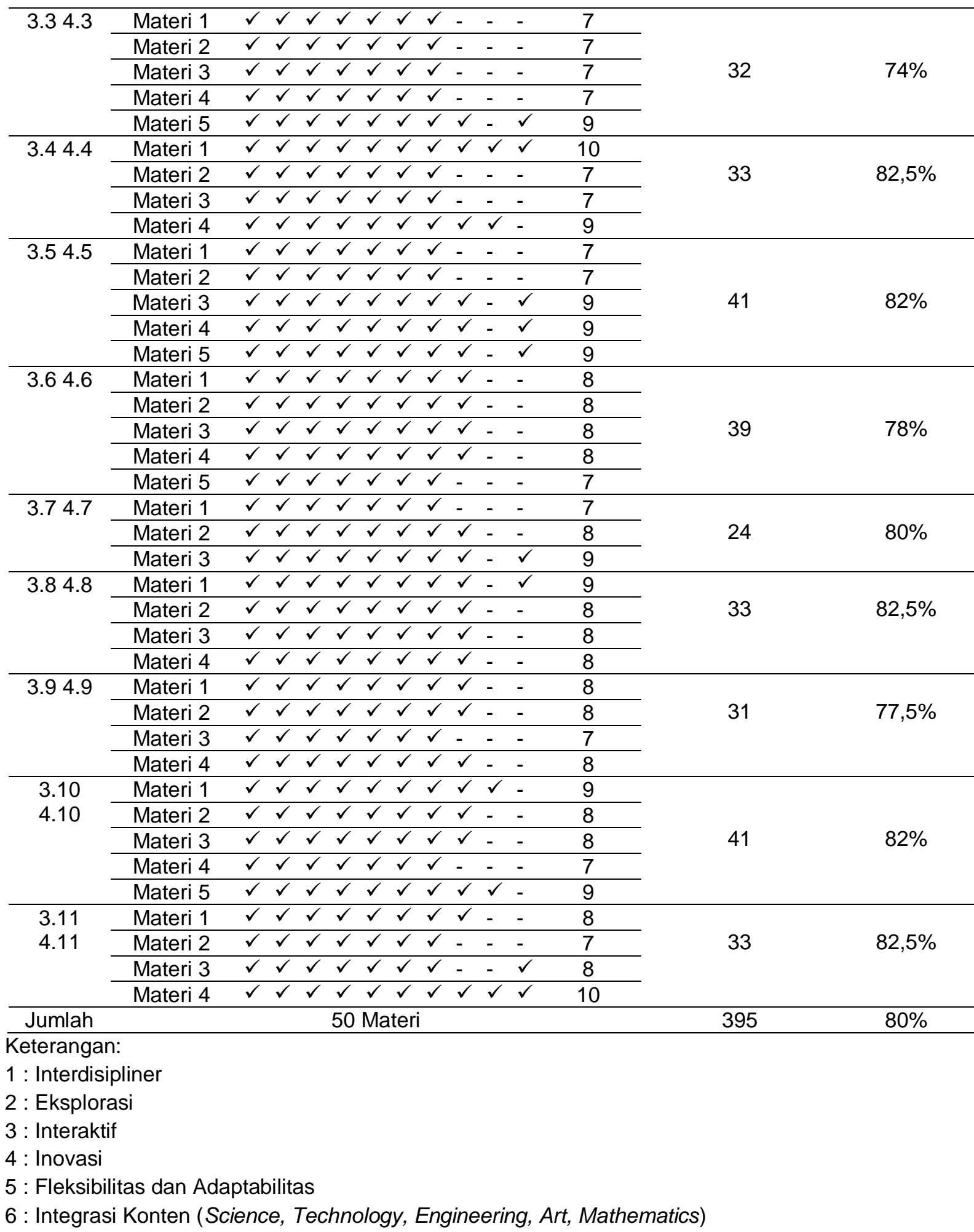

Berdasarkan pada tabel 3 di atas, diperoleh data bahwa setiap materi dalam kompetensi dasar 3.1 4.1 hingga 3.11 4.11 terdapat kegiatan pembiasaan literasi, namun tidak semua materi dalam kompetensi dasar tersebut memiliki kegiatan proyek. Beberapa materi yang memiliki kegiatan proyek juga tidak semuanya optimal untuk berpotensi STEAM (Science, Technology, Engineering, Art, Mathematics) 
karena tidak mencakup semua indikator yang dibutuhkan. Dari total 50 materi yang terbagi dalam 11 kompetensi dasar, memiliki jumlah skor sebanyak 395 yang mencakup materi yang sangat berpotensi, cukup berpotensi, dan tidak berpotensi STEAM (Science, Technology, Engineering, Art, Mathematics) dengan presentase total sebesar $80 \%$.

Berdasarkan materi pada 11 kompetensi dasar yang telah dianalisis, hanya 2 materi yang sangat berpotensi terhadap penerapan STEAM dengan skor 10 sebagai skor tertinggi, yaitu pada materi 1 kompetensi dasar 3.44 .4 yaitu materi ciri-ciri virus, struktur, dan reproduksinya; materi 4 kompetensi dasar 3.114 .11 yaitu materi penanganan limbah karena pada kedua materi tersebut telah memenuhi semua indikator STEAM. Materi yang cukup berpotensi terhadap penerapan STEAM dengan skor 8-9 terdapat pada 3 materi pada kompetensi dasar 3.1 4.1; 4 materi pada Kompetensi Dasar 3.2 4.2; 1 Materi pada Kompetensi Dasar 3.3 4.3; 1 materi pada Kompetensi Dasar 3.4 4.4; 3 materi pada Kompetensi Dasar 3.5 4.5; 4 materi pada Kompetensi Dasar 3.6 4.6; 2 materi pada Kompetensi Dasar 3.7 4.7; 4 materi pada Kompetensi Dasar 3.8 4.8; 3 materi pada Kompetensi Dasar 3.9 4.9; 4 materi pada Kompetensi Dasar 3.10 4.10; 2 materi pada Kompetensi Dasar 3.11 4.11. Materi yang tidak berpotensi terhadap STEAM dimiliki oleh 10 Kompetensi Dasar dengan total skor 6-7 karena pada integrasi konten belum mencakup semua indikator pada integrasi konten yang meliputi Science, Technology, Engineering, Art, Mathematics. Hal ini dapat dikatakan bahwa tidak semua kegiatan dalam pembelajaran dapat berpotensi terhadap STEAM. Apabila guru lebih kreatif dan inovatif maka fakta yang ada dapat dibuat potensi STEAM. Terdapat beberapa contoh fakta pada Kompetensi Dasar yang berpotensi STEAM sebagai berikut.

Materi yang sudah berpotensi STEAM dapat dilihat pada Kompetensi Dasar 3.11 4.11 materi 4 yaitu "Penanganan Limbah" melalui pemberikan tugas proyek dengan memperhatikan pendekatan STEAM sesuai dengan indikator yang dibutuhkan. Pertama, pendekatan Science adalah mengetahui jenis-jenis limbah, proses daur ulang dan 3R (Reuse, Reduce, Recycle) bahwa beberapa jenis limbah dapat didaur ulang dengan cara yang sesuai. Kedua, pendekatan Technology berupa penggunaan internet untuk membuka tutorial pembuatan kerajinan berbahan dasar limbah melalui video di youtube dan mencari tahu informasi tambahan yang dibutuhkan dalam kegiatan proses daur ulang limbah. Ketiga, pendekatan Engineering bahwa pembuatan produk kerajinan tangan berbahan dasar limbah diawali dengan mengumpulkan alat dan bahan yang digunakan, selanjutnya adalah membuat pola dari limbah yang digunakan sehingga akan membentuk desain dari kerajinan tangan yang akan dibuat. Keempat, pendekatan Art terlihat dari kreativitas masing-masing siswa dalam membuat kerajinan berbahan dasar limbah. Kelima, pendekatan Mathematics terlihat pada saat siswa menentukan jumlah limbah yang akan digunakan sesuai dengan kebutuhan dan saat siswa menggunakan penggaris untuk mengukur bahan yang dibutuhkan serta pemotongan bahan sehingga dapat membentuk pola yang sesuai dengan kerajinan yang akan dibuat. Tugas proyek 
yang diterapkan menggunakan pembelajaran STEAM pada materi ini dapat mengembangkan kemampuan dan keterampilan pada setiap peserta didik.

Contoh lain mengenai potensi STEAM terdapat pada Kompetensi Dasar 3.9 4.9 materi 1 yaitu ciri-ciri umum hewan invertebrata (lapisan tubuh, rongga tubuh, simetri tubuh, dan reproduksi) belum berpotensi terhadap pembelajaran STEAM karena materi tersebut belum memenuhi aspek Art dan Mathematics dari STEAM. Potensi STEAM dapat diterapkan pada materi tersebut melalui pemberian tugas proyek kepada siswa yang dapat mendukung kegiatan belajar mengajar. Pertama, pendekatan Science adalah ciri-ciri umum hewan invertebrata yang meliputi perbandingan kompleksitas lapisan penyusun tubuh (diploblastik dan triploblastik), simetri tubuh, rongga tubuh, dan reproduksinya sebagai pengantar dalam menyampaikan materi pokok sehingga dapat membantu siswa dalam proses pengamatan. Kedua, pendekatan Technology berupa penggunaan internet untuk mencari informasi tambahan yang diperlukan dalam mengidentifikasi hasil pengamatan. Ketiga, pendekatan Engineering yaitu dengan menyiapkan alat dan bahan yang dibutuhkan untuk melakukan pengamatan, dilanjutkan dengan kegiatan pengamatan dan mengidentifikasi ciri umum dari hewan yang diamati. Keempat, pendekatan Art adalah dengan membuat lukisan yang menunjukkan ciri umum hewan yang diamati dengan kreativitas masing-masing siswa menggunakan warna tinta yang menarik. Kelima, pendekatan Mathematics yaitu jumlah objek yang digunakan untuk pengamatan untuk membantu proses identifikasi dan membuat garis serta bentuk lapisan tubuh, simetri tubuh, rongga tubuh, reproduksi dari hewanhewan yang diamati. Tugas proyek dapat diterapkan pembelajaran STEAM yang dugunakan pada saat proses belajar untuk mengembangkan kemampuan dan keterampilan setiap siswa.

Hasil analisis menunjukkan beberapa materi berpotensi STEAM karena memenuhi kriteria indikator yang diperlukan yaitu aspek sains, teknologi, teknik, seni dan matematika. Salah satu penunjang dalam aktivitas pembelajaran STEAM adalah penggunaan literatur yang berbasis IT, yang menggabungkan penggunaan Teknologi Informasi dan Komunikasi dengan multimedia yang dapat memacu siswa untuk mampu berpikir kreatif, bekerja secara kreatif dan menciptakan inovasi baru dalam belajar sehingga dapat menciptakan pembelajaran yang menarik dan bermakna (Trilling dan Fadel, 2009). Wilson \& Hawkins (2019) juga menyatakan bahwa pembelajaran STEAM membuat siswa menghargai bagaimana seni dan sains bersama-sama menggunakan banyak bentuk keterampilan berpikir kritis, kreativitas, dan imajinasi ketika mereka mencoba memahami berbagai masalah nyata. Namun, beberapa materi yang ditemukan pada kompetensi dasar belum berpotensi STEAM karena belum diterapkan kegiatan proyek dalam pembelajaran. Untuk mengatasi permasalahan tersebut maka perlu meningkatkan keterampilan guru yang diperlukan dalam kegiatan belajar mengajar, seperti melalui workshop atau pelatihan guru mengenai penyususnan rencana pembelajaran STEAM hingga pelaksanaan pembelajaran STEAM di kelas (Sartono, et al., 2020). 
Hasil analisis yang peneliti kembangkan pada Buku Paket sesuai Kurikulum 2013 Bidang Studi Biologi SMA Kelas X mengenai kegiatan proses belajar mengajar yang berpotensi STEAM (Science, Technology, Engineering, Art, Mathematics) untuk dapat mengembangkan dan meningkatkan kemampuan yang ada pada setiap siswa. Pada buku paket Biologi SMA Kelas $X$ ada beberapa kompetensi dasar yang materinya sudah berpotensi STEAM, tetapi ada pula yang belum berpotensi STEAM karena materi tersebut tidak mencakup semua indikator yang diperlukan untuk dapat diterapkan pembelajaran STEAM. Untuk itu, diharapkan guru dapat mengembangkan pembelajaran yang lebih kreatif, inovatif, imajinatif, dan menyenangkan sehingga dapat membentuk pengalaman belajar yang bermakna pada siswa.

Berdasarkan hasil analisis yang dilakukan, didapatkan fakta bahwa pada Buku Paket Biologi SMA Kelas $X$ yang terdiri atas 11 kompetensi dasar dan 50 materi dalam buku tersebut, 2 materi sangat berpotensi STEAM, 31 materi cukup berpotensi STEAM, 17 materi tidak berpotensi STEAM. Diharapkan potensi STEAM yang ada dapat digunakan guru sebagai acuan dalam kegiatan belajar mengajar sehingga dapat meningkatkan kemampuan dan keterampilan pada setiap peserta didik.

\section{SIMPULAN DAN SARAN}

Berdasarkan hasil penelitian dapat disimpulkan bahwa Kompetensi Dasar kurikulum 2013 Bidang Studi Biologi SMA Kelas X yang telah dianalisis cukup berpotensi untuk diterapkan pembelajaran STEAM dengan kualifikasi 17 materi tidak berpotensi STEAM karena materi tersebut belum memenuhi kriteria indikator yang dibutuhkan untuk diterapkan pembelajaran STEAM (Science, Technology, Engineering, Art, Mathematics), 31 materi cukup berpotensi untuk diterapkan pembelajaran STEAM, dan 2 materi sangat berpotensi untuk diterapkan pembelajaran STEAM. Potensi STEAM yang sudah ada diharapkan dapat digunakan dan dikembangkan secara maksimal oleh guru dalam kegiatan melajar mengajar.

\section{RUJUKAN}

Al Faris, F. (2015). Kurikulum 2013 dalam perspektif filsafat pendidikan progressivisme. Jurnal Filsafat, 25(2), 316-338.

Annisa, R., Effendi, M. H., \& Damris, D. (2018). Peningkatan Kemampuan Berpikir Kreatif Siswa dengan Menggunakan Model Project Based Learning Berbasis STEAM (Science, Technology, Engineering, Art dan Mathematic) pada Materi Asam dan Basa di SMAN 11 Kota Jambi. Journal of The Indonesian Society of Integrated Chemistry, 10(2), 14-22.

Apriliana, M. R., Ridwan, A., Hadinugrahaningsih, T., \& Rahmawati, Y. (2018). Pengembangan Soft Skills Peserta Didik melalui Integrasi Pendekatan Science, Technology, Engineering, Arts, and Mathematics (STEAM) dalam Pembelajaran Asam Basa. JRPK: Jurnal Riset Pendidikan Kimia, 8(2), 4251. 
Coates, D.E,. (2020). People Skill Training: Are You Getting a return on Your Investmen, Designing for Immersive Technology: Integrating Art and STEM Learning. The STEAM Journal,, 16(3), 19-25.

Daugherty, M. K. (2013). The prospect of an "A" in STEM education. Journal of STEM Education: Innovations and Research, 14(2), 10-15.

DeCoito, I. (2014). Focusing on Science, Technology, Engineering, and Mathematics (STEM) in the 21st Century. Ontario Professional Surveyor, 57(1), 34-36.

Ernst, J., Williams, T., Clark, A., Kelly, D., \& Sutton, K. (2018). K-12 STEM Educator Autonomy: An Investigation of School Influence and Classroom Control. Journal of STEM Education, 18(5).

Fattal, Laura Rachel. (2019). Case studies on the transfer of knowledge within the interdisciplinary STEAM curricula construct. The STEAM Journal:Vol. 4:Iss. 1, 1-10.

Hadinuraningsih, Tritiyatma dkk. 2017. Keterampilan Abad 21 dan STEAM (Science, Technology, Engineering, Art, Mathematics) Project dalam Pembelajaran Kimia. Jakarta: Universitas Negeri Jakarta http://sipeg.unj.ac.id/repository/upload/buku/Keterampilan Abad 21 dan S TEAM Project dalam Pembelajaran Kimia.pdf

Handayani, Meni. (2018). Pemanfaatan Sarana Laboratorium di SMA yang Telah dan Belum Melaksanakan Kurikulum 2013. Jurnal Pendidikan dan Kebudayaan, 3(2), 152-166.

Hunter, Tracey. Doginer. (2019). STEAM Afterschool and Summer Learning. The STEAM Journal:Vol. 4:Iss. 1, 1-10.

Kastawi, N., Widodo, S., \& Mulyaningrum, E. (2017). Kendala dalam implementasi kurikulum 2013 di Jawa Tengah dan strategi penanganannya. Indonesian Journal of Curriculum and Educational Technology Studies, 5(2), 66-76.

Kezar, A., Gehrke, S., \& Elrod, S. (2015). Implicit theories of change as a barrier to change on college campuses: An examination of STEM reform. The Review of Higher Education, 38(4), 479-506.

Lestari, N. D. (2018). Analisis Penerapan Kurikulum 2013 dalam Meningkatkan Kualitas Pembelajaran Ekonomi di SMA Negeri se-Kota Palembang. Jurnal Neraca: Jurnal Pendidikan dan IImu Ekonomi Akuntansi, 2(1).

Liliawati, W., Rusnayati, H., \& Aristantia, G. (2018). Implementation of STEAM Education to Improve Mastery Concept. In IOP Conference Series: Materials Science and Engineering (Vol. 288, No. 1, p. 012148). IOP Publishing.

Mardiana, S., \& Sumiyatun, S. (2017). Implementasi Kurikulum 2013 Dalam Pembelajaran Sejarah Di Sma Negeri 1 Metro. HISTORIA Jurnal Program Studi Pendidikan Sejarah, 5(1), 45-54.

Nur, M. (2011). Modul Keterampilan Proses Sains. Surabaya: Pusat Sains dan Matematika Sekolah, Universitas Negeri Surabaya

Nurhikmayati, lik. (2019). Implementasi STEAM dalam Pembelajaran Matematika. Junal Didactical Mathematics 1(2), 41-50.

Park, H., Byun, S., Sim, J., Han, H., \& Baek,Y. S. (2016). Teachers'perceptions andpractices of STEAM education in South Korea. Eurasia Journal of Mathematics, Science, \& Technology Education, 12(7), 1739-1753. https://doi.org/10.12973/Eurasia.2016.1531a 
Patresia, I., Silitonga, M., \& Ginting, A. (2020). Developing biology students' worksheet based on STEAM to empower science process skills. JPBI (Jurnal Pendidikan Biologi Indonesia), 6(1), 147-156.

Perignat, E. and Katz-Buonincontro, J. 2018. STEAM in Practice and Research: An Integrative Literature Review. Thinking Skills and Creativity 31: 31-43.

Perignat, E., \& Katz-Buonincontro, J. (2019). STEAM in practice and research: An integrative literature review. Thinking Skills and Creativity, 31, 31-43.

Permendikbud. (2013). No. 69 tahun 2013 Tentang Kerangka Dasar dan Struktur Kurikulum Sekolah Menengah Atas/Madrasah Aliyah

Plucker, J. A., Guo, J., \& Dilley, A. (2018). guided programs and strategies for nurturing creativity.

Prameswari, Titania Widya \& Lestariningrun, Anik (2020). STEAM Based Learning Strategies by Playing Loose Parts for the Achievement of 4C Skills in Children 4-5 Years, Vol. 7 No.1

Pratiwi, S. N., Cari, C., \& Aminah, N. S. (2019). Pembelajaran IPA Abad 21 dengan Literasi Sains Siswa. Jurnal Materi dan Pembelajaran Fisika, 9(1), 34-42.

Rabkin, N., \& Hedberg, E. C. (2011). Arts Education in America: What the Declines Mean for Arts Participation. Based on the 2008 Survey of Public Participation in the Arts. Research Report\# 52. National Endowment for the Arts.

Rachim, Fathur. 2019. How to STEAM Your Classroom Revo 4.0 Model - Outside The Box (Part-1). Jakarta:DPP Asosiasi Guru Teknologi Informasi Indonesia https://www.academia.edu/40290341/HOW TO STEAM YOUR CLASSR OOM REVO 40 MODEL

Ramadani, Etika. (2020). Pengembangan Handout Matematika Berbasis Pendekatan STEAM (Science, Technology, Engineering, Arts, and Mathematics) Pada Materi Bangun Ruang Sisi Datar Untuk Siswa Kelas VIII SMP (Doctoral Dissertation, FKIP).

Ranam, S., \& Amaliah, D. (2017). Pendekatan Contextual Teaching Learning dalam Pembelajaran Berbasis Kurikulum 2013. Research and Development Journal of Education, 3(2), 131-143.

Retnowati, L., Sugianto, S., \& Alimah, S. (2020). The Development of Integrated Biology-Entrepreneurship Learning Design Based STEAM. Journal of Innovative Science Education, 9(3), 124-129.

Rustaman, N. Y. (2016). Pembelajaran Sains Masa Depan Berbasis STEM Education. Prosiding Seminar Nasional Biologi Edukasi 2016, 1-16.

Rustaman, N.Y. (2011). Pendidikan dan Penelitian Sains Dalam Mengembangkan Keterampilan Berpikir Tingkat Tinggi Untuk Pembangunan Karakter, Vol. 8, No. 1. Makalah Seminar Nasional VIII P.Biologi, FKIP UNS, Surakarta.

Sanders, M. E. (2008). Stem, stem education, stemmania.

Sartono, N., Suryanda, A., Ahmad, T. L. S., Zubaidah, Z., \& Yulisnaeni, Y. (2020). Implemetasi STEAM dalam Pembelajaran Biologi: Upaya Pemberdayaan Guru Biologi Madrasah Aliyah DKI Jakarta. BAKTIMAS: Jurnal Pengabdian pada Masyarakat, 2(1), 7-14.

Shalikhah, N. D. (2016). Pemanfaatan aplikasi Lectora Inspire sebagai media pembelajaran interaktif. Cakrawala: Jurnal Studi Islam, 11(1), 101-115. 
Siswanto, J. (2018). Keefektifan Pembelajaran Fisika dengan Pendekatan STEM untuk Meningkatkan Kreativitas Mahasiswa. Jurnal Penelitian Pembelajaran Fisika, 9(2), 133-137.

Subandi, S. (2014). Pengembangan Kurikulum 2013 (Studi Analitis dan Subtantif Kebijakan Kurikulum Nasional). Terampil: Jurnal Pendidikan dan Pembelajaran Dasar, 1(1), 18-36.

Sudarisman, S. (2015). Memahami hakikat dan karakteristik pembelajaran biologi dalam upaya menjawab tantangan abad 21 serta optimalisasi implementasi kurikulum 2013. Florea: Jurnal Biologi dan Pembelajarannya, 2(1).

Sugiyono. (2014). Metode Penelitian Pendidikan Pendekatan Kuantitatif, Kualitatif, dan R\&D. Bandung: Alfabeta.

Sukmana, R. W. (2018). Pendekatan Science, Technology, Engineering And Mathematics (STEM) Sebagai Alternatif dalam Mengembangkan Minat Belajar Peserta Didik Sekolah Dasar. Pendas: Jurnal IImiah Pendidikan Dasar, 2(2), 189-197.

Suwono, H., Rizkita, L., \& Susilo, H. (2017). Peningkatan literasi saintifik siswa sma melalui pembelajaran biologi berbasis masalah sosiosains. Jurnal IImu Pendidikan, 21(2).

Thien, L.M., Darmawan, I.G.N. \& Ong, M.Y. (2015). Affective characteristics and mathematics performance in Indonesia, Malaysia, and Thailand: what can PISA 2012 data tell us?. Large-scale Assess Educ 3, 3.

Thuneberg, H., Salmi, H., \& Fenyvesi, K. (2017). Hands-on math and art exhibition promoting science attitudes and educational plans. Education Research International, 1-13.

Trilling, B., \& Fadel, C. (2009). 21st century skills: Learning for life in our times. John Wiley \& Sons.

Ulva, V., Ibrohim, I., \& Sutopo, S. (2017). Mengembangkan Sikap IImiah Siswa SMP Melalui Pembelajaran Inkuiri Terbimbing Pada Materi Ekosistem. Jurnal Pendidikan: Teori, Penelitian, dan Pengembangan, 2(5), 622-626.

Vossoughi, S., Hooper, P. K., \& Escude, M. (2016). Making Through The Lens of Culture and Power: Toward Transformative Visions for Educational Equity. Harvard Educational Review: Summer 2016, Vol. 86, No. 2, pp. 206-232. https://doi.org/10.17763/0017-8055.86.2.206.

Wijaya, A. D., Karmila, N. I. L. A., \& Amalia, M. R. (2015). Implementasi Pembelajaran Berbasis STEAM (Science, Technology, Engineering, Art, Mathematics) pada Kurikulum Indonesia, 85-88. In Proseding Seminar Nasional Fisika dan Aplikasinya. Tersedia Online: portal. phys. unpad. ac. id.

Wijaya, E. Y., Sudjimat, D. A., Nyoto, A., \& Malang, U. N. (2016). Transformasi pendidikan abad 21 sebagai tuntutan pengembangan sumber daya manusia di era global. In Prosiding Seminar Nasional Pendidikan Matematika (Vol. 1, No. 26, pp. 263-278).

Wilson, B. \& Hawkins, B. 2019. Art and Science in a Transdisciplinary Curriculum. In Judson, G. \& Lima, J. (Eds). CIRCE Magazine: Steam Edition. CIRCE: The Centre for Imagination in Research, Culture \& Education

Zubaidah, S. (2016). Keterampilan abad ke-21: Keterampilan yang diajarkan melalui pembelajaran. In Seminar Nasional Pendidikan dengan Tema "isu-isu strategis pembelajaran MIPA Abad (Vol. 21, No. 10). 
Zubaidah, S. (2019). STEAM (Science, Technology, Engineering, Arts, and Mathematics): Pembelajaran untuk Memberdayakan Keterampilan Abad ke21. In Seminar Nasional Matematika dan Sains dengan Tema "STEAM Terintegrasi Kearifan Lokal dalam Menghadapi Era Revolusi Industri (Vol. 4). 